\title{
Use of Monoclonal Antibodies to Determine Biomass of Cladosporium fulvum in Infected Tomato Leaves
}

\author{
Natalia Karpovich-Tate, Pietro Spanu, and Frances M. Dewey \\ Department of Plant Sciences, University of Oxford, South Parks Road, Oxford OX1 3RB, U.K. \\ Accepted 25 March 1998.
}

\begin{abstract}
A monoclonal antibody, OX-CH1, was raised against surface washings of Cladosporium herbarum. This antibody recognizes an epitope that is found in various fungi belonging to the genus Cladosporium, including $C$. fulvum, the causal agent of tomato leaf mold. The epitope is present at comparable levels in two different races of $C$. fulvum and in transgenic isolates derived from them. The epitope is heat- and protease-resistant but sensitive to oxidation with periodate and it is constitutively expressed in C. fulvum grown in pure culture and on the plant. $C$. fulvum can be detected in infected tissues at levels starting from around $1 \mathrm{mg}$ fresh weight of fungus per $\mathrm{g}$ fresh weight of leaf tissue. Noninfected tomato leaves do not cross-react with OX-CH1. We have developed an enzymelinked immunosorbent assay (ELISA) for fungal biomass in tomato leaves and compared it with the assay based on measurements of $\beta$-glucuronidase (GUS) activity in tissues infected with a transgenic isolate of $C$. fulvum race 4 carrying a uidA gene; the two assays give similar results.
\end{abstract}

Additional keywords: PTA-ELISA, quantitative.

There is a need in plant pathology to be able to quantify, at all stages of infection, the extent of vegetative growth of specific fungal pathogens within host tissues. However, few satisfactory methods of determining the biomass of fungi in vivo are available (Dewey et al. 1997) and almost no attempt has been made to compare and validate such methods.

Counting colonies on leaf surfaces or the measurement of the surface area producing spores have been used as indicators of the level of infection of phylloplane pathogens such as Erysiphe and Botrytis (Newton and Reglinski 1993; Elad et al. 1994; Köhl et al. 1995) but such methods do not give quantitative information about the early stages of infection or the extent of growth in vivo. Measurements of vegetative fungal growth in vivo have mostly relied on quantification of constituents, such as chitin and ergosterol (Ride and Drysdale 1972; Hicks and Newell 1983; Lumsden et al. 1990). Such methods are not very sensitive and are limited because specific fungal populations cannot be selectively measured (Lumsden et al. 1990). Furthermore, some markers have been shown to relate poorly to the biomass of the fungus in ques-

Corresponding author: F. M. Dewey; Telephone: +44 (0)1865 275116; Fax: +44 (0)1865 275116; E-mail: molly.dewey@plants.ox.ac.uk tion (Bermingham et al. 1995b). Alternative techniques include molecular methods based on the use of nucleic acid primers with internal control standards (Nicholson et al. 1996; $\mathrm{Hu}$ et al. 1993; Robb et al. 1994), measurement of $\beta$ glucuronidase (GUS) activity in GUS transformants (Oliver et al. 1993), and immunological methods.

Nucleic-acid-based methods of detection have the advantage of being extremely sensitive and specific but, while they have proved very useful in epidemiological studies on the spread of specific isolates, their use for quantitative studies of pathogens in plant tissues is often difficult; interference from nonfungal substances present in host plant extracts, such as phenols, is a common problem (Johanson 1994; Miller 1996). In contrast, measurement of the levels of GUS activity in plant tissues is straightforward but limited to studies with isolates that carry a uidA transgene. Immunoassays are relatively robust, easy to perform and to replicate, and have proved useful in the detection and quantification of fungi grown in axenic culture but their use in the detection and quantification of fungal pathogens in plants and mixed microbial populations has been limited by the difficulty of producing antisera (i.e., polyclonal antibodies, PAbs) that are specific to the pathogen. Antisera raised to mycelial fragments or culture fluids frequently cross-react with related and unrelated fungi and with extracts from host tissues (Dewey and Thornton 1995; Miller 1996). In some cases this can be reduced by cross-adsorption against host and other fungal tissues but the resulting titer is often greatly reduced and the specificity is generally not reproducible (Mohan 1989). Nevertheless, successful enzyme-linked immunosorbent assays (ELISAs) employing antisera have been reported by Ricker et al. (1991) for Botrytis cinerea in grape juice, by Harrison et al. (1990) and Beckman et al. (1994) for Phytophthora infestans in potato leaves, and by Newton and Reglinski (1993) for Erysiphe graminis in barley leaves. Development of quantitative assays employing genusor species-specific monoclonal antibodies (MAbs) holds considerably more promise. Kessel et al. (1997) used a neargenus-specific MAb to quantify, by digital image analysis, the extent of growth of $B$. cinerea in diseased lily leaves in the presence of the biocontrol agent Ulocladium atrum. Genus- or species-specific MAbs have also been employed in ELISAs to quantify Humicola lanuginosa in rice grains (Dewey et al. 1992), the eyespot pathogen Pseudocercosporella herpotrichoides in winter cereals (Priestley and Dewey 1993), Rhizoctonia solani and Trichoderma harzianum in soils 
(Thornton et al. 1993; Thornton and Dewey 1996), aquatic hyphomycetes growing on decaying leaves in streams (Bermingham et al. 1995a), and Verticillium dahliae in potato stems (Plasencia et al. 1996).

In an unrelated study, in which we were raising MAbs to Cladosporium herbarum, we obtained a number of genusspecific MAbs, one of which, OX-CH1, has proved useful in the quantification of $C$. fulvum in tomato leaves. This paper discusses the suitability of $\mathrm{OX}-\mathrm{CH} 1$, in plate trapped antigen (PTA)-ELISAs, to measure the biomass of $C$. fulvum in infected tomato leaves at different stages after infection, and validation of this method by comparison with biomass measurements with a $C$. fulvum strain expressing a uidA gene.

\section{RESULTS}

Production and screening of hybridoma cell lines.

Three fusions were carried out with splenocytes from mice immunized with either germinating or nongerminating spores of $C$. herbarum. Very few cell lines that secreted MAbs that recognized the immunogen were obtained from these fusions and, of these, none were specific. However, three more fusions were carried out with splenocytes from mice immunized with surface washings of cultures of $C$. herbarum. From these fusions, nine cell lines that recognized the immunogen $C$. herbarum were obtained, and of these five recognized antigens from both $C$. herbarum and $C$. fulvum. The four cell lines with the highest absorbance values in PTA-ELISAs against surface antigens of $C$. fulvum race $4-\mathrm{OX}-\mathrm{CH} 1, \mathrm{OX}-\mathrm{CH} 8, \mathrm{OX}-\mathrm{CH} 10$, and $\mathrm{OX}-\mathrm{CH} 11$ - were selected for further study. Supernatants from these cell lines were tested against surface antigens from a range of related and unrelated fungi and all were genusspecific. The results obtained with OX-CHI are shown in Figure 1 . Of the four cell lines selected for further study, supernatants from the cell line OX-CH1 gave the highest absorbance values and the greatest difference between extracts from infected and healthy leaves. This cell line was therefore chosen for the development of an immunological biomass assay.

\section{Development of biomass assay.}

Phosphate-buffered saline (PBS) was found to be the best buffer for extracting mycelial antigens from infected leaves and freeze-dried mycelium. An extract of 1/5 (wt/vol) from infected tomato leaves gave the highest difference and the least cross-reactivity between extracts from healthy and infected tomato leaves. However, with heavily infected leaves we found that it was necessary to use higher dilutions. The final assay system adopted was one in which a $1 / 5(\mathrm{wt} / \mathrm{vol})$ extract was prepared from frozen ground leaves and further diluted in PBS to give $1 / 10,1 / 20,1 / 40$, and $1 / 80$ extracts. Infected leaves were tested in triplicate at the same time as a set of mycelial antigen reference standards. For reference standards a cell-free PBS extract from a stock of freeze-dried mycelium of $C$. fulvum $\left(1 \mathrm{mg} \mathrm{ml}^{-1}\right)$ diluted into PBS was used. This dilution series was found to give a very satisfactory standard calibration curve with absorbance values in each assay being proportional to the concentration of antigens in the extract over the range of 1 to $62.5 \mu \mathrm{g} \mathrm{ml}^{-1}$ (Fig. 2). The biomass

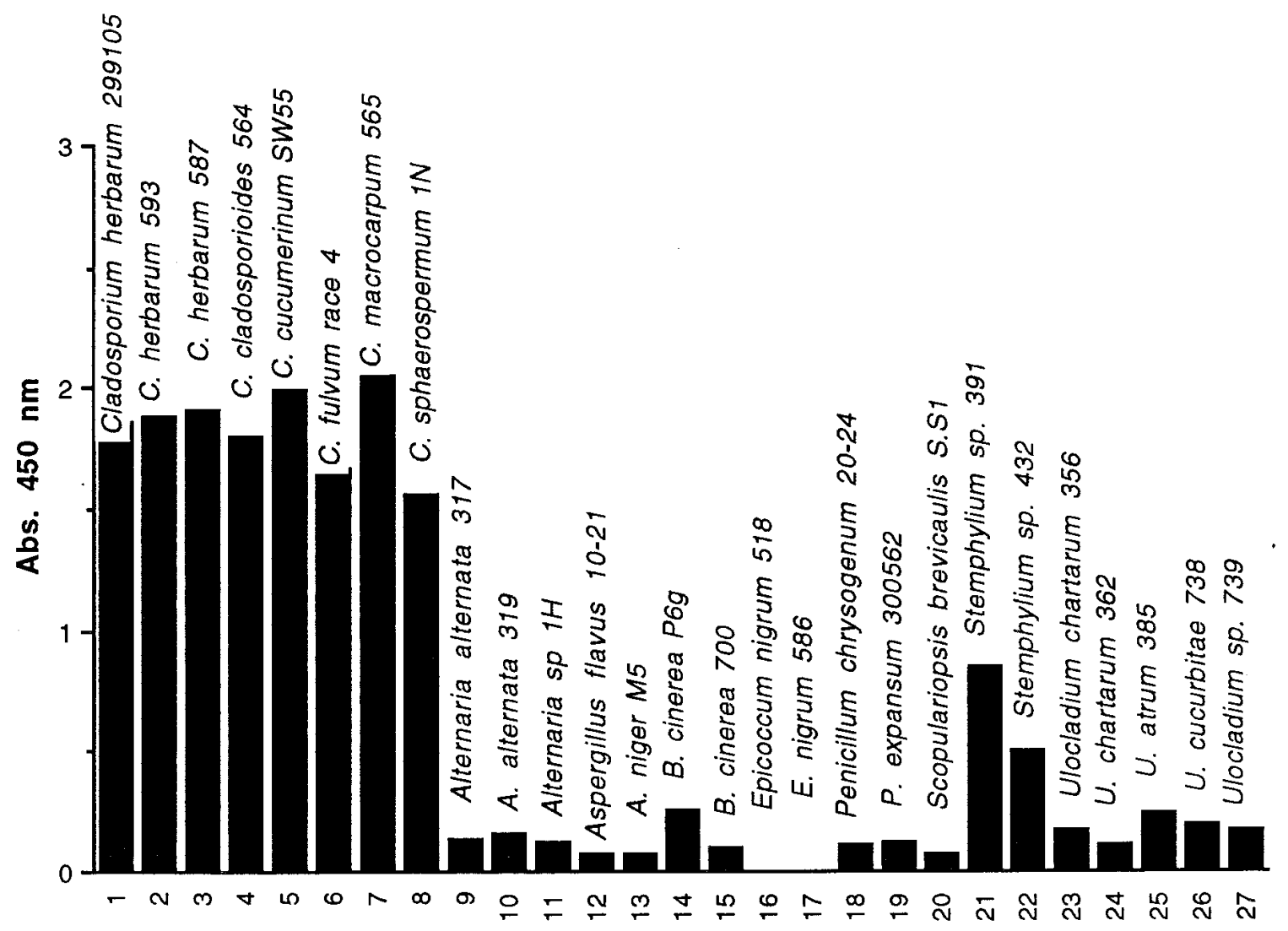

Fig. 1. Plate trapped antigen-enzyme-linked immunosorbent assay of monoclonal antibody OX-CH1 against surface washings of selected fungi. 
of mycelium in infected leaves was estimated by inverse prediction from the calibration curve. It is necessary to run a set of reference standards with each set of assays because the absolute values for absorbance vary from day to day (cf. Sutula 1996).

\section{Determination of antibody immunoglobulin class} and characterization of antigen.

All four chosen antibodies (OX-CH1, OX-CH8, OX-CH10, and $\mathrm{OX}-\mathrm{CH} 11)$ were immunotyped and identified as $\mathrm{IgM}$ MAbs. The antigens recognized by these MAbs were characterized by heat, protease, and periodate treatment and by chemical deglycosylation. The epitopes recognized by these MAbs were only slightly sensitive to boiling, autoclaving, freeze/thawing, and prolonged protease treatment. In PTAELISAs when the antigens were pre-treated with periodate the absorbance values for all four antibodies were reduced by around $60 \%$ and were almost completely eliminated by chemical deglycosylation with the Oxford GlycoSciences kit. The results indicate that $\mathrm{OX}-\mathrm{CH} 1, \mathrm{OX}-\mathrm{CH} 8, \mathrm{OX}-\mathrm{CH} 10$, and OX-CH11 all recognize carbohydrate epitopes, on either a carbohydrate or glycoprotein molecule.

\section{Effect of age and differences between isolates} on antigen production.

In vitro cultures of $C$. fulvum race 4 of different ages had comparable quantities of the OX-CH1 antigen. The abundance of the OX-CH1 antigen in different races of $C$. fulvum, and transgenic strains derived from these, was compared. Equivalent signals were obtained in all four isolates tested (Fig. 2).

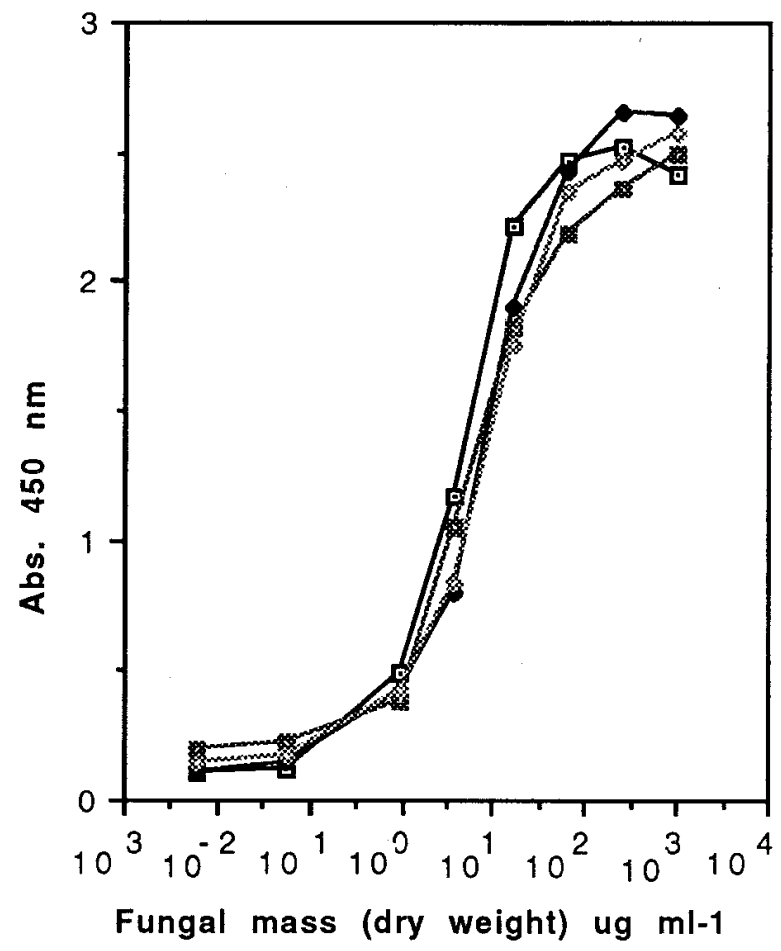

Fig. 2. Calibration curve with monoclonal antibody $\mathrm{OX}-\mathrm{CH} 1$ tested by plate trapped antigen-enzyme-linked immunosorbent assay against fourfold dilutions $(100 \mu \mathrm{l}$ per well) of a phosphate-buffered saline extract of lyophilized mycelium of Cladosporium fulvum race 4 (dotted squares), race 4 transformed with the uidA gene (filled-in squares), race 4 strain 85 (filled-in diamonds), and race 5 (open diamonds).
Comparison of GUS-based and immuno-biomass assays (PTA-ELISAs) in quantification of mycelium in leaves at different stages post-infection.

The PTA-ELISA was directly compared with a GUS-based assay by measuring fungal biomass in tomato leaves infected with a $C$. fulvum isolate carrying a transgenic uidA gene. Both the PTA-ELISA and the GUS assay could detect the fungus at very low levels $\left(<1 \mathrm{mg} \mathrm{g}^{-1}\right)$ in infected leaves immediately after inoculation (Fig. 3). No GUS activity or OX-CH1 antigen could be detected in uninoculated plants (not shown). After a lag phase of about 7 days the fungal colonization of the leaf followed a period of exponential growth. The course of infection, as determined by the two methods, was equivalent except for the later stages of infection when the GUS activity increased between 14 and 18 days after inoculation, reaching $21 \mathrm{mg} \mathrm{g}^{-1}$ fresh weight, whereas fungal biomass measured by PTA-ELISA remained constant at approximately $15 \mathrm{mg} \mathrm{g}^{-1}$. This experiment was performed 3 times and the data presented in Figure 3 are representative of the results obtained.

\section{DISCUSSION}

This study has shown that the progress of infection of $C$. fulvum in infected tomato leaves can be measured by determining fungal biomass with the genus-specific MAb OX-CH1 in a PTA-ELISA.

The genus-specific hybridoma cell line secreting the MAb, $\mathrm{OX}-\mathrm{CH} 1$, used for the development of the biomass assay was produced from splenocytes of mice immunized with saline surface washings of $C$. herbarum. The fact that nine poten-

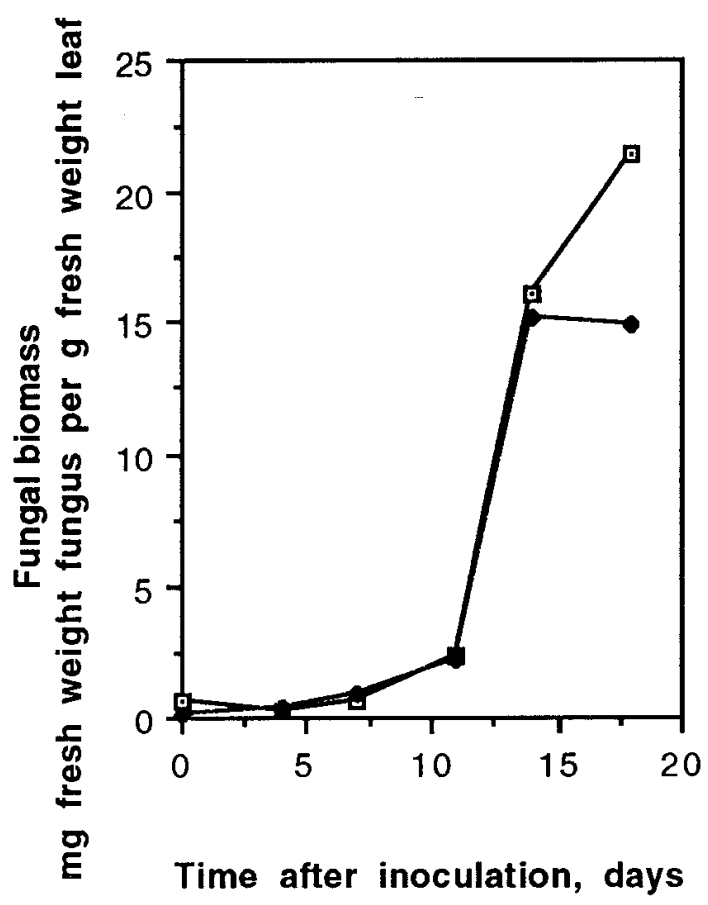

Fig. 3. Biomass of the Cladosporium fulvum race 4 carrying the uidA gene, in infected tomato leaves determined by plate trapped antigenenzyme-linked immunosorbent assay (PT-ELISA) and by measuring $\beta$ glucuronidase (GUS) activity. Tomato plants were inoculated and the leaves sampled immediately after inoculation (0) and at 4, 7, 11, 14, and 18 days thereafter. GUS assays, dotted squares. PTA-ELISAs, filled-in diamonds. 
tially useful cell lines were raised with surface washings as the immunogen whereas none were raised from splenocytes of mice immunized with a suspension of spores or germinating spores confirms that surface washings of fungi are a good source of immunogens for producing specific MAbs (Bermingham et al. 1995a, 1995b; Dewey and Thornton 1995). The lack of immunogenicity of germinating spores of $C$. herbarum is surprising because this fungus is well known to be allergenic (Aukhurst and Borch 1984; Breitenbach et al. 1997). It is interesting that the four MAbs that were genusspecific all belonged to the immunoglobulin class IgM and recognized heat-stable, periodate-sensitive, carbohydrate epitopes. In previous studies we have also found that the genus-specific MAbs, almost without exception, belong to the immunoglobulin class IgM and recognize heat-stable, carbohydrate epitopes (Dewey and Thornton 1995; Dewey et al. 1997).

The use of MAbs to determine biomass of fungal material in infected plants has been reported before but in only a few cases has any attempt been made to validate these measurements by alternative methods (Dewey et al. 1992, 1997). A transgenic strain of C. fulvum expressing GUS activity has been used successfully to determine the biomass of this strain in infected leaf tissues (Oliver et al. 1993), to compare the activity of $C$. fulvum resistance genes in tomato, and to identify other genes required for full expression of $C$. fulvum gene resistance (Hammond-Kosack et al. 1994). We therefore chose to compare directly the biomass assay by PTA-ELISA with the GUS-based assay by measuring OXCH1 activity in tomato leaves infected with a $C$. fulvum strain carrying a GUS reporter gene. We found that the two methods gave remarkably similar results with regard to both sensitivity and course of infection. The only difference is that whereas the GUS activity in infected leaves still increased in the very last stages of infection (14 to 18 days), in the PTA-ELISAs there appears to be a stabilization of the signal. This difference was found to occur reproducibly. It could reflect a difference in the nature of the two assays and it is difficult to tell which of the two parameters best reflects fungal biomass at this stage. One possibility is that at the later stages of the infection cycle a large proportion of the biomass is represented by spores and that $\mathrm{OX}-\mathrm{CH} 1$ does not recognize spores. This, however, has not proved to be the case, as we have found that the antibody does recognize $C$. fulvum spores quantitatively (results not shown). Alternatively, because GUS activity is very stable in infected leaves, in spite of stasis in fungal growth, the total activity of the enzyme being produced could increase and could accumulate even in the absence of an increase in fungal mass. It is also possible that the fungal antigen recognized by OX$\mathrm{CH} 1$ is subject to degradation by plant hydrolytic enzymes known to be produced during the later stages of infection (Joosten and de Wit 1989). Our data cannot distinguish between the last two possibilities. The GUS assay is sensitive and easy to carry out. It is, however, limited to those isolates that have been artificially transformed with the bacterial uidA gene. In this respect the PTA-ELISA is of greater general applicability as it can be employed for a variety of different isolates of $C$. fulvum and does not require the use of transgenic organisms; hence, the PTA-ELISA is the method of choice if such limitations are of importance.
It is necessary to run a set of reference standards with each set of PTA-ELISAs because of the inherent day-to-day variation in all ELISAs (Sutula 1996; Dewey et al. 1997). Reference standards can easily be prepared from a stock of freezedried mycelium. It is worth noting that we found that a dilution series of the mycelial antigens in PBS alone gave almost the same absorbance values as mycelial antigens plus extracts from healthy tomato leaves, and so for all comparative purposes a simple dilution series of the mycelial antigens in PBS is sufficient.

The amount of antigen produced by each isolate remained almost constant at all stages of growth of cultures in vitro. This suggests that the epitope recognized by $\mathrm{OX}-\mathrm{CH} 1$ is continuously expressed and is a reliable indicator of fungal biomass, confirming the comparative data obtained in vivo with isolates expressing GUS activity.

In conclusion, we have raised MAbs and developed an ELISA-based method for the detection and quantification of C. fulvum in infected tomato leaves. The assay is robust and simple to use. We believe this assay will be of great help, for example, in the analysis of the effects of directed mutations on the pathogenicity of the fungus, in identifying new pathogenicity genes in C. fulvum, and for comparing quantitatively the course of infection in the interaction between different races of the pathogen in tomato plants expressing different resistance genes.

\section{MATERIALS AND METHODS}

\section{Tomato plants and inoculation.}

Tomato seeds (cv. Money Maker) were sown in peat-based compost (Astro, Goundrey \& Son, Oxford, UK) and placed in the greenhouse. Three weeks after sowing, the seedlings were transplanted into individual pots $(10 \mathrm{~cm}$ diameter) in peatbased compost. Natural light was supplemented with artificial illumination to produce a $16-\mathrm{h}$ day and 8 -h night. The tomato plants were inoculated 4 to 5 weeks after sowing. Prior to inoculation, the plants were decapitated, leaving 3 or 4 fully expanded leaves. Spore suspensions (approximately $5 \times 10^{6}$ spores $\mathrm{ml}^{-1}$ in water) of C. fulvum were sprayed onto the underside of the fully expanded leaflets. The plants were then placed for $24 \mathrm{~h}$ in closed, humidified chambers in the greenhouse. The chambers were subsequently opened. Samples of six leaflets from different plants were taken and frozen at $-80^{\circ} \mathrm{C}$.

\section{Fungal cultures.}

MAbs were raised against a strain of Cladosporium herbarum (IMI 299105). Cultures of C. fulvum races 4 and 5 and the transgenic derivatives of wild-type race 4 strain 85 and uidA were obtained from the collection of P. Spanu. C. fulvum race 4 was used for all experiments unless otherwise stated. Cultures of $C$. fulvum were maintained on potato dextrose agar (Oxoid) and liquid cultures were grown in B5 medium (Gamborg et al. 1968) for 2 days. For details of isolates of other fungi used for screening hybridoma supernatants and methods of culture see Table 1 .

\section{Preparation of PBS extracts from freeze-dried mycelium.}

Mycelium from liquid cultures was ground in liquid nitrogen, freeze-dried, and extracted with PBS $(0.8 \% \mathrm{NaCl} ; 0.02 \%$ $\left.\mathrm{KCl} ; 0.115 \% \mathrm{Na}_{2} \mathrm{HPO}_{4} ; 0.02 \% \mathrm{KH}_{2} \mathrm{PO}_{4} ; \mathrm{pH} 7.2\right)\left(1 \mathrm{mg} \mathrm{ml}{ }^{-1}\right)$ 
for $30 \mathrm{~min}$. For the set of reference standards the cell-free supernatant from this extract was used to coat microtiter wells by fourfold dilutions into further PBS.

\section{Preparation of immunogen and immunization regime.}

Ten- to 14-day-old cultures of $C$. herbarum in petri dishes were washed with $5 \mathrm{ml}$ of PBS. The surface washings were filtered through a $70-\mu \mathrm{m}$ pore size sterile nylon cell strainer (Becton Dickinson Labware, Franklin Lakes, NJ) to remove mycelial fragments, and then centrifuged at $12,000 \times g$ to remove spores. The supernatant that was used as the immunogen was aliquoted and stored at $-20^{\circ} \mathrm{C}$ prior to use. Three 6week-old $\mathrm{BALB} / \mathrm{c}$ female mice were each given three intraperitoneal injections (300 $\mu \mathrm{l}$ per injection) of the immunogen, at 2-week intervals, to which Quil A adjuvant (Superfos, Vedbaek, Denmark) had been added to give a final concentration of $0.01 \%$.

Table 1. List of fungi used for screening antibodies, source, and conditions of growth

\begin{tabular}{|c|c|c|c|c|}
\hline Fungal cultures & Isolate & Source $^{a}$ & Medium $^{b}$ & Temp. \\
\hline Alternaria alternata & 317 & IPO & $\mathrm{OA}$ & $20^{\circ} \mathrm{C}$ \\
\hline Alternaria alternata & 319 & IPO & OA & $20^{\circ} \mathrm{C}$ \\
\hline Alternaria alternata & $1 \mathrm{H}$ & NKT & PDA & $20^{\circ} \mathrm{C}$ \\
\hline Alternaria sp. & 3 & SW & PDA & $20^{\circ} \mathrm{C}$ \\
\hline Aspergillus flavus & $10-21$ & FMD & PDA & $25^{\circ} \mathrm{C}$ \\
\hline Aspergillus flavus & $10-1$ & FMD & PDA & $25^{\circ} \mathrm{C}$ \\
\hline Aspergillus niger & D & FMD & PDA & $25^{\circ} \mathrm{C}$ \\
\hline Aspergillus niger & M5 & FMD & PDA & $25^{\circ} \mathrm{C}$ \\
\hline Botrytis cinerea & P69 & FMD & PDA & $18^{\circ} \mathrm{C}$ \\
\hline Botrytis cinerea & 700 & IPO & PDA & $18^{\circ} \mathrm{C}$ \\
\hline Cladosporium cladosporioides & 549 & IPO & $\mathrm{OA}$ & $20^{\circ} \mathrm{C}$ \\
\hline Cladosporium cladosporioides & 564 & IPO & OA & $20^{\circ} \mathrm{C}$ \\
\hline Cladosporium сиситеrinum & 55 & SW & PDA & $20^{\circ} \mathrm{C}$ \\
\hline Cladosporium fulvum & race 4 & PS & PDA & $20^{\circ} \mathrm{C}$ \\
\hline Cladosporium fulvum & $\begin{array}{c}\text { race } 4 \\
\text { strain } 85\end{array}$ & PS & PDA & $20^{\circ} \mathrm{C}$ \\
\hline Cladosporium fulvum & $\begin{array}{l}\text { race } 4 \\
\text { TuidA }\end{array}$ & PS & PDA & $20^{\circ} \mathrm{C}$ \\
\hline Cladosporium fulvum & race 5 & PS & PDA & $20^{\circ} \mathrm{C}$ \\
\hline Cladosporium herbarum & 299105 & IMI & PDA & $20^{\circ} \mathrm{C}$ \\
\hline Cladosporium herbarum & 587 & IPO & $\mathrm{OA}$ & $20^{\circ} \mathrm{C}$ \\
\hline Cladosporium herbarum & 593 & IPO & OA & $20^{\circ} \mathrm{C}$ \\
\hline Cladosporium macrocarpum & 557 & IPO & $\mathrm{OA}$ & $20^{\circ} \mathrm{C}$ \\
\hline Cladosporium macrocarpum & 565 & IPO & $\mathrm{OA}$ & $20^{\circ} \mathrm{C}$ \\
\hline Cladosporium sphaerospermum & $1 \mathrm{~N}$ & NKT & PDA & $20^{\circ} \mathrm{C}$ \\
\hline Epicoccum nigrum & 506 & IPO & $\mathrm{OA}$ & $20^{\circ} \mathrm{C}$ \\
\hline Epicoccum nigrum & 518 & IPO & $\mathrm{OA}$ & $20^{\circ} \mathrm{C}$ \\
\hline Penicillium chrysogenum & $20-24$ & SW & PDA & $20^{\circ} \mathrm{C}$ \\
\hline Penicillium expansum & 300562 & IMI & PDA & $20^{\circ} \mathrm{C}$ \\
\hline Scopulariopsis brevicaulis & S.S1 & FMD & PDA & $20^{\circ} \mathrm{C}$ \\
\hline Stemphylium sp. & 391 & IPO & $\mathrm{OA}$ & $20^{\circ} \mathrm{C}$ \\
\hline Stemphylium sp. & 432 & IPO & $\mathrm{OA}$ & $20^{\circ} \mathrm{C}$ \\
\hline Ulocladium atrum & 385 & IPO & OA & $20^{\circ} \mathrm{C}$ \\
\hline Ulocladium chartarum & 356 & IPO & OA & $20^{\circ} \mathrm{C}$ \\
\hline Ulocladium chartarum & 362 & IPO & OA & $20^{\circ} \mathrm{C}$ \\
\hline Ulocladium cucurbitae & 738 & IPO & OA & $20^{\circ} \mathrm{C}$ \\
\hline Ulocladium sp. & 739 & IPO & $\mathrm{OA}$ & $20^{\circ} \mathrm{C}$ \\
\hline
\end{tabular}

${ }^{a}$ FMD: F. M. Dewey; SW: S. Watkinson; PS: P. Spanu; and NKT: N. Karpovich-Tate, Department of Plant Sciences, University of Oxford, England. IMI: International Mycological Institute, Egham, England; IPO: Institut voor Planteziektenk, Onderzoek, Wageningen, the Netherlands.

${ }^{\mathrm{b}} \mathrm{OA}$ : oat agar (20 $\mathrm{g}$ of milled oat, $15 \mathrm{~g}$ of agar, and 1 liter of tap water); PDA: potato dextrose agar (Oxoid).

\section{Production and screening of hybridomas for antibody specificity.}

Hybridoma cells were produced by the method described by Dewey et al. (1989), and the supernatants screened by PTA-ELISA against surface washings and germinated spores of $C$. herbarum immobilized in microtiter wells. Wells were arranged in strips and coated with $50 \mu$ of either cell-free PBS surface washings from 10- to 14-day-old potato dextrose agar (PDA, Oxoid, CM149) or oat agar (OA, see Table 1 for details) plate cultures of fungal isolates diluted fourfold in PBS or spore suspensions in $2 \%$ glucose $\left(5 \times 10^{4}\right.$ spores $\mathrm{ml}^{-1}$ ). Supernatants from positive clones were further tested by PTA-ELISA against surface washings and germinating spores of other fungi.

\section{ELISA formats.}

Screening of hybridoma supernatants was performed by PTA-ELISA with microtiter wells (Lab Systems, Helsinki, Finland, 9502037) coated with either fourfold dilutions of PBS surface washings from 10-day-old plate culture of $C$. herbarum IMI or germinated spores in $2 \%$ glucose $\left(5 \times 10^{6}\right.$ spores $\mathrm{ml}^{-1}$ ). Wells with surface washings were incubated at $4^{\circ} \mathrm{C}$ overnight, whereas wells with spore suspension were incubated overnight at $24^{\circ} \mathrm{C}$ or $37^{\circ} \mathrm{C}$ (Aspergillus spp.) to allow germination of the spores. Coated wells were washed four times with PBS and air dried at $24^{\circ} \mathrm{C}$ in a laminar flow hood. The strips were either stored in sealed polythene bags at $4^{\circ} \mathrm{C}$ or used directly. Washed wells containing immobilized antigen were incubated successively with hybridoma supernatant, goat anti-mouse polyvalent immunoglobulin (classes IgG, IgA, and IgM) peroxidase conjugate (Sigma, Poole, Dorset, UK, A-0412), and the substrate tetramethyl benzidine with washings with PBST (PBS plus $0.05 \%$ Tween 20) between incubations as given in Bossi and Dewey (1992). Absorbance values were read on an ELISA automated microplate reader (MRX, Dynatech, Billinghurst, Sussex, UK). Working volumes for the hybridoma screening assays were $50 \mu \mathrm{l}$ per well and all incubations were performed at room temperature.

The PTA-ELISAs for biomass were essentially the same as above except that all working volumes were 100 and 200 $\mu \mathrm{l}$ for the blocking step. Wells were coated in triplicate with PBS extracts from frozen tomato leaf powder $(1 / 5, \mathrm{wt} / \mathrm{vol})$ that had been centrifuged at $12,000 \times g$ for $15 \mathrm{~min}$. After incubation overnight at $4^{\circ} \mathrm{C}$ wells were washed 4 times in PBS and then blocked with $0.3 \%(\mathrm{wt} / \mathrm{vol})$ casein in PBS. Then the wells were incubated successively with the MAb for $1 \mathrm{~h}$ and with goat anti-mouse polyvalent peroxidase conjugate (Sigma, A-0412) for another hour. Bound antibody was visualized by incubating wells with tetramethyl benzidine substrate solution for $30 \mathrm{~min}$. Reaction was stopped by adding $100 \mu \mathrm{l}$ of $3 \mathrm{M} \mathrm{H}_{2} \mathrm{SO}_{4}$, and absorbance values were read on an ELISA automated microplate reader (Dynatech MRX). Between the incubations, wells were rinsed 4 times with PBST. Assays of test samples were always done in triplicate. With each set of assays a dilution series of mycelial antigen standards was always included. A standard curve of absorbance against mycelial antigen concentration was plotted and from this the antigen values of the test samples determined accordingly. 
Determination of Ig subclass and cloning procedure.

The Ig subclass of MAbs from selected cell lines was determined with a commercial MAb isotyping kit according to manufacturer's instructions (Sigma, ISO-1). Hybridoma cell lines were cloned by limiting dilution, and selected cell lines were grown in bulk in a nonselective medium, preserved by slowly freezing in fetal bovine serum/dimethyl sulfoxide (92:8 [vol/vol]), and maintained in liquid nitrogen.

\section{Antigen characterization.}

Protease digestion of immobilized antigen was carried out by PTA-ELISA on wells coated with doubling dilutions of surface washings of $C$. fulvum race 4 . After the coated wells were washed with PBS, they were incubated with pronase (Sigma, P-5147), $0.25 \mathrm{U}$ per well, at $37^{\circ} \mathrm{C}$ for different periods of time ranging from $5 \mathrm{~min}$ to $24 \mathrm{~h}$, then washed three times for $5 \mathrm{~min}$ with PBST, blocked with casein $(0.3 \%$ [wt/vol], in PBS) for $30 \mathrm{~min}$, and assayed by PTA-ELISA with OX-CH1 MAb. Control wells were treated with PBS.

The effect of heat treatment on antigenic material from the cell-free surface washings, diluted 1 in 4 in PBS, from 10day-old PDA plate culture of C. fulvum race 4, was determined by boiling for 5,30 , and $60 \mathrm{~min}$ or autoclaving at $121^{\circ} \mathrm{C}$ for $20 \mathrm{~min}$, cooling, centrifuging at $12,000 \times g$ for 5 min, and then double diluting into PBS (50 $\mu$ per well). After immobilization overnight at $4{ }^{\circ} \mathrm{C}$, wells were washed, blocked with casein $(0.3 \%$ [wt/vol], in PBS) for $30 \mathrm{~min}$, and assayed by PTA-ELISA with OX-CH1. Nontreated surface washings served as a positive control.

The effect of periodate oxidation on immobilized antigens was determined by incubating wells coated with doubling dilutions of surface washings of $C$. fulvum race $4(50 \mu \mathrm{l}$ per well) with $50 \mu$ of sodium metaperiodate $(20 \mathrm{mM} \mathrm{NaIO}$ in $50 \mathrm{mM}$ sodium acetate buffer, $\mathrm{pH}$ 4.5) (Sigma, S-1878) for different periods of time ranging from $5 \mathrm{~min}$ to $24 \mathrm{~h}$, in darkness at $4^{\circ} \mathrm{C}$; control wells were incubated with buffer alone. Wells were then given three 5-min washes with PBST, blocked with casein $(0.3 \%$ [wt/vol], in PBS) for $30 \mathrm{~min}$, and then assayed by PTA-ELISA with OX-CH1.

Deglycosylation of antigens was carried out on cell-free surface washings of $C$. fulvum race 4 diluted fourfold with PBS and initially dialyzed overnight at $4{ }^{\circ} \mathrm{C}$ against $0.1 \%$ ( $\mathrm{vol} / \mathrm{vol}$ ) trifluoroacetic acid and then transferred to the bottom of a glass reaction vial and lyophilized. Deglycosylation was performed with the GlycoFree Deglycosylation Kit (Oxford GlycoSciences, Abingdon, Oxon, UK, K-500) according to the manufacturer's instruction. Deglycosylated surface washings were again dialyzed overnight at $4^{\circ} \mathrm{C}$ against ammonium bicarbonate buffer, plated into microtiter wells (50 $\mu \mathrm{l}$ per well) by the method of doubling dilutions as described earlier for immobilization overnight at $4{ }^{\circ} \mathrm{C}$, blocked with casein $(0.3 \%$ [wt/vol], in PBS) for $30 \mathrm{~min}$, and processed for PTA-ELISA. Nontreated surface washings and surface washings dialyzed overnight at $4^{\circ} \mathrm{C}$ against $0.1 \%$ (vol/vol) trifluoroacetic acid were used as controls.

\section{GUS assays.}

GUS activity in the leaves infected with an isolate of $C$. fulvum race 4 transformed with uidA gene was determined with the fluorometric assay with methylumbelliferone as a sub- strate (Jefferson 1987). Standards were measured with extracts from the GUS-expressing C. fulvum grown in vitro.

\section{ACKNOWLEDGMENTS}

We would like to thank J. Tree and J. Bond for technical assistance. N. K.-T. was supported by a pump-priming grant from Oxford University, P. S. by the Royal Society, and F. M. D. by the Leverhulme Trust.

\section{LITERATURE CITED}

Aukhurst, L., and Borch, M. 1984. Allergens of Cladosporium. Pages 25-28 in: Atlas of Moulds in Europe. K. Wilken-Jensen and S. Gravesen, eds. ASK, Copenhagen.

Beckman, K. B., Harrison, J. G., and Ingram, D. S. 1994. Optimization of a polyclonal enzyme-linked immunosorbent assay (ELISA) of fungal biomass for use in studies of plant defence responses. Physiol. Mol. Plant Pathol. 44:19-32.

Bermingham, S., Dewey, F. M., and Maltby, L. 1995a. Development of a monoclonal antibody-based immunoassay for the detection and quantification of Anguillospora longissima colonizing leaf material. Appl. Environ. Microbiol. 61:2606-2613.

Bermingham, S., Maltby, L., and Cooke, R. C. 1995b. A critical assessment of the validity of ergosterol as an indicator of fungal biomass. Mycol. Res. 99:479-484.

Bossi, R., and Dewey, F. M. 1992. Development of a monoclonal antibody-based immunodetection assay for Botrytis cinerea. Plant Pathol. 41:472-482.

Breitenbach, M., Simon, B., Probst, G., Oberkofler, H., Ferreira, F., Briza, P., Achatz, G., Unger, A., Ebner, C., Kraft, D., and Hirschwehr, R. 1997. Enolases are highly conserved fungal allergens. Int. Arch. Allergy Appl. Immunol. 113:114-117.

Dewey, F. M., MacDonald, M. M., and Phillips, S. I. 1989. Development of monoclonal-antibody -ELISA, DOT-BLOT and DIP-STICK immunoassays for Humicola lanuginosa in rice. J. Gen. Microbiol. 135: 361-374.

Dewey, F. M., and Thornton, C. R. 1995. Fungal immunodiagnostics in plant agriculture. Pages 151-170 in: New Diagnostics in Crop Sciences. J. H. Skerritt and R. Appels, eds. CAB Int., Cambridge University Press, Cambridge.

Dewey, F. M., Thornton, C. R., and Gilligan, C. A. 1997. Use of monoclonal antibodies to detect, quantify and visualise fungi in soils. Adv. Bot. Res. 24:276-308.

Dewey, F. M., Twiddy, D. R., Phillips, S. I., Grose, M. J., and Wareing, P. W. 1992. Development of a quantitative monoclonal antibodybased immunoassay for Humicola lanuginosa on rice grains and comparison with conventional assays. Food Agric. Immunol. 4:153-167.

Elad, Y., Köhl, J., and Fokkema, N. J. 1994. Control of infection and sporulation of Botrytis cinerea on bean and tomato by saprophytic yeasts. Phytopathology 84:1193-1200.

Gamborg, O. L., Miller, R. A., and Ojima, K. 1968. Nutrient requirements of suspension cultures of soybean root cells. Exp. Cell Res. 50:148-151.

Hammond-Kosack, K. E., Jones, D. A., and Jones, J. D. G. 1994. Identification of 2 genes required in tomato for full Cf-9-dependent resistance to Cladosporium fulvum. Plant Cell 6:361-374.

Harrison, J. G., Barker, H., Lowe, R., and Rees, E. A. 1990. Estimation of amounts of Phytophthora infestans mycelium in leaf tissue by enzyme-linked immunosorbent assay. Plant Pathol. 39:274-277.

Hicks, R. E., and Newell, S. Y. 1983. An improved gas chromatographic method for measuring glucosamine and muric acid concentrations. Anal. Biochem. 128:438-445.

Hu. X., Nazar, R. N., and Robb, J. 1993. Quantification of Verticillium biomass in wilt disease development. Physiol. Mol. Plant Pathol. 42: 23-36.

Jefferson, R. A. 1987. Assaying chimaeric genes in plants: The GUS gene fusion system. Plant Mol. Biol. Rep. 5:387-405.

Johanson, A. 1994. PCR for detection of the fungi that cause Sigatoka leaf spots of banana and plantain. Page 215-221 in: Modern Assays for Plant Pathogenic Fungi: Identification, Detection and Quantification. A. Schots, F. M. Dewey, and R. P. Oliver, eds. CAB Int., Cambridge University Press, Cambridge. 
Joosten, M. H. A. J., and de Wit, P. J. G. M. 1989. Identification of several pathogenesis-related proteins in tomato leaves inoculated with Cladosporium fulvum (syn. Fulvia fulva) as 1.3-ss-glucanases and chitinases. Plant Physiol. 89:945-951.

Kessel, G. J. T., Lombaers-van der Plas, C. H., Meijer, E. M. J., Köhl, J., and van der Werf, W. 1997. Quantification of fungal biomass of a pathogen and an antagonist in necrotic leaf tissue using fluorescence microscopy and image analysis. Pages 237-238 in: Diagnostics and Identification of Plant Pathogens. H.-W. Dehne, G. Adam, M. Diekmann, J. Frahm, A. Mauler-Machnik, and P. van Halteren, eds. Kluwer Academic Pub., Dordrecht, The Netherlands.

Köhl, J., van der Plas, C. H., Molhoek, W. M. L., and Fokkema, N. J. 1995. Effect of leaf wetness periods on suppression of sporulation of Botrytis allii and B. cinerea by antagonists on dead onion leaves. Eur. J. Plant Pathol. 101:627-637.

Lumsden, R. D., Carter, J. P., Whipps, J. M., and Lynch, J. M. 1990. Comparison of biomass and viable propagule measurements in the antagonism of Trichoderma harzianum against Rhizoctonia ultimum. Soil Biol. Biochem. 22:187-194.

Miller, S. A. 1996. Detecting propagules of plant pathogenic fungi. Adv. Bot. Res. 23:278-102.

Mohan, S. B. 1989. Cross-reactivity of antiserum raised against Phytophthora fragariae for detecting the red core disease of strawberries by enzyme-linked immunosorbent assay. Plant Pathol. 37:206-216.

Newton, A. C., and Reglinski, T. 1993. An enzyme-linked immunosorbent assay for quantifying mildew biomass. Z. Pflanzenkrankh. Pflanzenschutz 100:176-179.

Nicholson, P., Lees, A. K., Maurin, N., Parry, D. W., and Rezanoor, H. H. 1996. Development of a PCR assay to identify and quantify $\mathrm{Mi}$ crodochium nivale var. nivale and Microdochium nivale var. majus in wheat. Physiol. Mol. Plant Pathol. 48:257-271.
Oliver, R. P., Farman, M. L., Jones, J. D. G., and Hammond-Kosack, K E. 1993. Use of fungal transformants expressing $\beta$-glucuronidase activity to detect infection and measure hyphal biomass in infected plant tissues. Mol. Plant-Microbe Interact. 6:521-525.

Plasencia, J., Jemmerson, R., and Banttari, E. E. 1996. Production and characterization of monoclonal antibodies to Verticillium dahliae and development of a quantitative immunoassay for fungal biomass. Phytopathology 86:170-176.

Priestley, R. A., and Dewey, F. M. 1993. Development of a monoclonal antibody immunoassay for the eyespot pathogen Pseudocercosporella herpotrichoides. Plant Pathol. 42:403-412.

Ricker, R. W., Marois, J. J., Dlott, J. W., Bostock, R. M., and Morrison, J. C. 1991. Immunodetection and quantification of Botrytis cinerea in harvested wine grapes. Phytopathology 81:404-411.

Ride, J. P., and Drysdale, R. D. 1972. A rapid method for chemical estimation of filamentous fungi in plant tissue. Physiol. Plant Pathol. 2:715.

Robb, J., Hu, X., Platt, H., and Nazar, R. 1994. PCR-based assays for the detection and quantification of Verticillium species in potato. Pages 83-90 in: Modern Assays for Plant Pathogenic Fungi: Identification, Detection and Quantification. A. Schots, F. M. Dewey, and R. P. Oliver, eds. CAB Int., Cambridge University Press, Cambridge.

Sutula, C. L. 1996. Quality control and cost effectiveness of indexing procedures. Adv. Bot. Res. 23:279-292.

Thornton, C. R., and Dewey, F. M. 1996. Detection of phialoconidia of Trichoderma harzianum in peat-bran by monoclonal antibody-based enzyme-linked immunosorbent assay. Mycol. Res. 135:361-374

Thornton, C. R., Dewey, F. M., and Gilligan, C. A. 1993. Development of monoclonal antibody-based immunological assays for the detection of live propagules of Rhizoctonia solani in soil. Plant Pathol. 42:763773 . 